\title{
Electrolyte and water distribution in familial hypokalaemic periodic paralysis
}

\author{
A. J. COPPEN AND E. H. REYNOLDS
}

\begin{abstract}
From the Medical Research Council Neuropsychiatric Research Unit, West Park Hospital, Epsom, Surrey, and The National Hospital for Nervous Diseases, Queen Square, London
\end{abstract}

There are contradictory reports on the intracellular concentrations of muscle electrolytes in familial hypokalaemic periodic paralysis. These are summarized in Table I. Grob, Johns, and Liljestrand (1957), studying arteriovenous differences of potassium, demonstrated that the fall in serum potassium during attacks of paralysis is due to the entry of potassium into muscle cells. Jantz (1947), Conn and Streeten (1960), and Talso, Glynn, Oester, and Fudema (1963) found an increase in intracellular potassium concentration during attacks, whereas Vastola and Bertrand (1956) and Shy, Wanko, Rowley, and Engel (1961) found a slight decrease, which the latter authors attributed to the entry of relatively greater amounts of water than potassium. These conflicting results probably arose from difficulties in the technique of chemical analysis of muscle biopsies and the small number of cases studied.

We present in this paper the results obtained, using a multiple isotope technique, in a study of the distribution of water and electrolytes in six cases of familial hypokalaemic periodic paralysis.

\section{PATIENTS}

The six patients had the typical clinical and bio- chemical characteristics of familial hypokalaemic periodic paralysis. The main clinical features are summarized in Table II. Patient 1 had not had an attack for 27 years and the diagnosis was made retrospectively when his son (patient 2) presented with the same symptoms. There was no family history of the disorder in the other cases. Patient 6 had developed a proximal myopathy (Oppenheim, 1891 ; Bekény, 1961 ; Pearson, 1964) and the muscle biopsy revealed a picture similar to that described by Pearson. This patient also had mild hypertension, cardiac enlargement, auricular fibrillation, and widespread inversion of $\mathbf{T}$-waves on his electrocardiogram. Cardiomyopathy has not, to our knowledge, been described in familial hypokalaemic periodic paralysis but Conn and Streeten (1960) drew attention to occasional accounts in the literature of hypertension, cardiac enlargement, and arrhythmia during attacks of paralysis and in this case the possibility of the condition being an associated cardiomyopathy remains an intriguing but unsettled question. He had been on treatment for two years with digoxin, $0.25 \mathrm{mg}$. b.d., and hydrochlorothiazide $25 \mathrm{mg}$. with potassium chloride $572 \mathrm{mg}$. daily.

Apart from the occasional occurrence of a myopathy it is usually stated that these patients are

TABLE I

REPORTED CHANGES IN POTASSIUM, SODIUM, AND WATER DISTRIBUTION AND DURING PERIOD OF PARALYSIS SUMMARIZED FROM THE LITERATURE

\begin{tabular}{|c|c|c|c|c|c|c|c|c|c|c|}
\hline \multirow[t]{2}{*}{ Author } & \multirow{2}{*}{$\begin{array}{l}\text { No. of } \\
\text { Cases }\end{array}$} & \multirow{2}{*}{$\begin{array}{l}\text { Total } \\
\text { Body } \\
\text { Water }\end{array}$} & \multicolumn{2}{|c|}{ Intracellular Water ${ }^{2}$} & \multirow[t]{2}{*}{$N a_{\mathbf{E}}$} & \multirow[t]{2}{*}{$\boldsymbol{K}_{\mathbf{E}}$} & \multicolumn{2}{|l|}{$[N a]_{\mathrm{In}^{2}}$} & \multicolumn{2}{|c|}{$[K]_{\mathrm{In}^{2}}$} \\
\hline & & & $\begin{array}{l}\text { Between } \\
\text { Attacks }\end{array}$ & $\begin{array}{l}\text { During } \\
\text { Attacks }\end{array}$ & & & $\begin{array}{l}\text { Between } \\
\text { Attacks }\end{array}$ & $\begin{array}{l}\text { During } \\
\text { Attacks }\end{array}$ & $\begin{array}{l}\text { Between } \\
\text { Attacks }\end{array}$ & $\begin{array}{l}\text { During } \\
\text { Attacks }\end{array}$ \\
\hline $\begin{array}{l}\text { Jantz (1947) } \\
\text { Vastola \& Bertrand (1956) }\end{array}$ & $\begin{array}{l}1 \\
1\end{array}$ & - & $\overline{\text { Normal }}$ & Increased & - & - & - & - & $\begin{array}{l}\text { Normal } \\
\text { Normal }\end{array}$ & $\begin{array}{l}\text { Increased } \\
\text { Slight } \\
\text { decrease }\end{array}$ \\
\hline Conn \& Streeten (1960) & 2 & - & - & - & $\begin{array}{l}\text { High normal } \\
\text { or high }\end{array}$ & Low & High & $\begin{array}{l}\text { Unchanged } \\
\text { or increased }\end{array}$ & Low & Increased \\
\hline Shy et al. (1961) & 1 & 一 & Normal & Increased & - & - & High & Decreased & Low & $\begin{array}{l}\text { Slight } \\
\text { decrease }\end{array}$ \\
\hline $\begin{array}{l}\text { Talso et al. (1963) } \\
\text { McArdle \& Merton (1952) } \\
\text { 'Same family } \\
\text { 'Derived from muscle biops }\end{array}$ & $5^{1}$ & $\begin{array}{l}\text { Normal } \\
-\end{array}$ & Normal & Unchanged & High & $\begin{array}{l}\text { Low normal } \\
\text { Low normal }\end{array}$ & High & Decreased & Low no & - \\
\hline
\end{tabular}


TABLE II

SUMMARY OF CLINICAL FEATURES OF PATIENTS

\begin{tabular}{|c|c|c|c|c|c|c|c|}
\hline $\begin{array}{l}\text { Hospital } \\
\text { No. }\end{array}$ & Patient & $\begin{array}{l}\text { Age } \\
(y r .)\end{array}$ & $\begin{array}{l}\text { Family } \\
\text { History }\end{array}$ & $\begin{array}{l}\text { Age of Onset } \\
(y r .)\end{array}$ & $\begin{array}{l}\text { Duration of Disease } \\
\text { (yr.) }\end{array}$ & $\begin{array}{l}\text { Average Frequency of Attacks } \\
\text { without Treatment }\end{array}$ & $\begin{array}{l}\text { Physical Condition between } \\
\text { Attacks }\end{array}$ \\
\hline $\begin{array}{l}\text { A19138 } \\
\text { A19138 } \\
75373\end{array}$ & $\begin{array}{l}1 \\
2 \\
3\end{array}$ & $\begin{array}{l}57 \\
16 \\
43\end{array}$ & $\begin{array}{l}+ \\
+ \\
-\end{array}$ & $\begin{array}{l}17 \\
13 \\
21\end{array}$ & $\begin{array}{r}40 \\
3 \\
22\end{array}$ & $\begin{array}{l}1 \text { per month until age } 30 \\
1 \text { per month } \\
1 \text { per month }\end{array}$ & $\begin{array}{l}\text { Normal } \\
\text { Normal } \\
\text { Slight reduction in exercise } \\
\text { tolerance }\end{array}$ \\
\hline 55077 & 4 & 31 & - & 20 & 11 & 2 per month & $\begin{array}{l}\text { Moderate reduction in exercise } \\
\text { tolerance }\end{array}$ \\
\hline $\begin{array}{l}\text { A8347 } \\
90546\end{array}$ & $\begin{array}{l}5 \\
6\end{array}$ & $\begin{array}{l}17 \\
60\end{array}$ & $\overline{-}$ & $\begin{array}{r}8 \\
28\end{array}$ & $\begin{array}{r}9 \\
32\end{array}$ & $\begin{array}{l}2 \text { per month } \\
3 \text { per year }\end{array}$ & $\begin{array}{l}\text { Normal } \\
\text { Progressive proximal myopathy } \\
\text { in last } 10 \text { years ? Cardio } \\
\text { myopathy }\end{array}$ \\
\hline
\end{tabular}

normal between attacks. This was only true of patients 1, 2, and 5 in this series. Patient 4 had quite marked reduction in exercise tolerance between attacks despite treatment with potassium supplements. The degree of this weakness was not even apparent to himself until he was also treated with a low-sodium diet, after which his performance on a bicycle ergometer improved by $700 \%$. Patient 3 and patient 6 , before the onset of myopathy, also had a slight reduction in exercise tolerance between attacks. Treatment with a low-sodium diet and potassium supplements for two months in patient 6 produced freedom from attacks of weakness, but it is too early to assess its effect on the myopathy.

\section{METHODS}

Distribution studies were carried out in four untreated patients; in one of these (patient 4) paralysis was induced and the tests were repeated five hours later at a time of severe weakness (M.R.C. grade 2 weakness in muscles of limbs and trunk). The patient was somewhat resistant to the measures used to induce paralysis which were $1 \mathrm{ml}$. adrenalin $(1: 1,000)$, followed within one hour by 40 units of soluble insulin and $35 \mathrm{~g}$. glucose. Paralysis was finally induced by $20 \mathrm{~g}$. of sodium bicarbonate orally. The electrolyte distribution of patient 5 was analysed at a time of almost complete recovery from an attack of paralysis which developed four hours earlier and from which he made a spontaneous recovery. We studied the effect on electrolyte distribution of a low-sodium diet (less than $25 \mathrm{mEq}$. daily) and potassium supplements (tab. potassium effervescent 5 g. b.d.) in two patients. Patient 4 was studied initially after he had been on this treatment for six months; he then continued the therapy for a further eight months when he resumed a normal diet for a further month so that we could retest him in the untreated state. Patient 6 was studied before and twoo months after this regime.

The technique employed to measure the distribution of water and electrolytes has been described in detail else- $\bigcirc$ where (Coppen and Shaw, 1963). Total body potassiumes was measured by estimating the activity from the natur- $\overrightarrow{0}$ ally occurring isotope of potassium ${ }^{40} \mathrm{~K}$ in a whole-body. counter. Exchangeable sodium, extracellular water, and total body water were estimated by a multiple isotopeo method using ${ }^{24} \mathrm{Na},{ }^{82} \mathrm{Br}$, and tritiated water. Other figures were derived from these variables and from theo concentrations of sodium, potassium, and chloride inis plasma.

Total body and intracellular potassium, exchangea sodium, residual sodium, and extracellular water ife correlated with body weight and even more highly cot-o related with total body water. Moore, Olesen, McMurre, Parker, Ball, and Boyden (1963) and also Anderson (1963) have published extensive data on the distribution \&fo sodium and potassium in normal subjects using te niques similar to our own and they give numerops $\overrightarrow{c o}$ regression equations relating exchangeable sodiumo and other variables to total body water. To analyse our data we have used these regression equations by employ-o ing a procedure proposed by Lindegård (1953) which has been utilized in a variety of anthropometric investigations. This technique can be illustrated by considering total body potassium. Anderson gives a regression equation $\mathbb{\varnothing}$ which enables the total body potassium of a normal subject to be predicted on the basis of his total body water. We applied this regression equation to our patients and 3 calculated the difference between the 'observed' and 'predicted' values of total body potassium. This difference? (using the convention introduced by Lindegård) is called residual $F$ total body potassium (total body water) This was determined for each patient for total body potas-:sium and also for the other variables which are highly correlated with total body water.

ESTIMATED AND DERIVED VALUES FOR WATER AND ELECTROLYTES

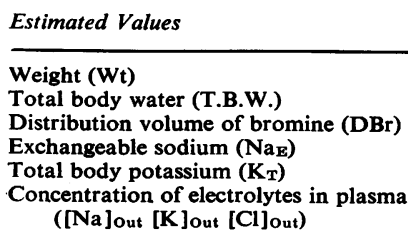

Unit $\mathbf{k g}$

1. 1. mEq. mEq.

$\mathrm{mEq} / 1$.

Derived Values
Extracellular water (E.C.W.)
Sodium in extracellular space Na out
Potassium in extracellular space $\mathrm{K}_{\text {out }}$
Residual sodium NaR
Residual sodium Concentration $[\mathrm{Na}]_{\text {In }}$
Residual potassium $\mathrm{K}_{\mathbf{R}}$
Intracellular potassium concentration
$[\mathrm{K}]_{\mathbf{I n}}$

$[\mathbf{K}]_{\mathbf{n}}$

\begin{tabular}{|c|c|}
\hline Derivation & Unit \\
\hline 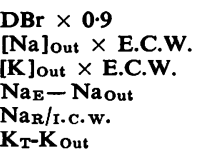 & $\begin{array}{l}1 . \\
\text { mEq. } \\
\text { mEq. } \\
\text { mEq. } \\
\text { mEq/l. } \\
\text { mEq. }\end{array}$ \\
\hline $\mathbf{K}_{R} / \mathbf{r} \cdot \mathbf{c} \cdot v$ & $\mathrm{mEq}$ \\
\hline
\end{tabular}


Values for intracellular water, extracellular water, and other derived values have been recalculated from the data for normal individuals published by Moore et al. (1963) using our own correction to the distribution of bromine to derive values for extracellular water.

The regression equations used in the paper are given elsewhere (Coppen and Shaw, 1965).

\section{RESULTS}

The results are presented in Tables III and IV. UNTREATED FAMILIAL HYPOKALAEMIC PERIODIC PARALYSIS These four patients showed a marked reduction in intracellular potassium concentration,

TABLE III

ELECTROLYTE AND WATER DISTRIBUTION IN SIX PATIENTS WITH FAMILIAL HYPOKALAEMIC PERIODIC PARALYSIS

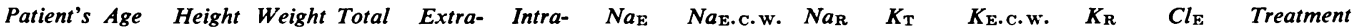

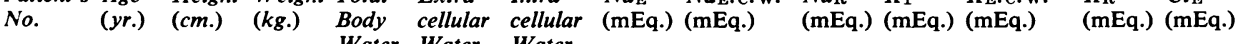

Water Water Water

(1.) (1.) (1.)

\begin{tabular}{|c|c|c|c|c|c|c|c|c|c|c|c|c|c|c|}
\hline \multicolumn{15}{|c|}{ Untreated } \\
\hline 1 & 57 & $174 \cdot 5$ & $77 \cdot 3$ & $38 \cdot 0$ & $18 \cdot 0$ & $20 \cdot 0$ & 2,860 & 2,420 & 440 & 2,860 & 77 & 2,780 & 2,180 & None \\
\hline 2 & 16 & $174 \cdot 5$ & $62 \cdot 4$ & $36 \cdot 1$ & $18 \cdot 2$ & $17 \cdot 9$ & 2,650 & 2,350 & 300 & 2,400 & 75 & 2,330 & 2,210 & None \\
\hline 3 & 43 & 180.0 & $85 \cdot 0$ & $47 \cdot 0$ & $19 \cdot 0$ & $28 \cdot 0$ & 3,060 & 2,700 & 360 & 3,550 & 97 & 3,450 & 2,270 & None \\
\hline 4 & 31 & $180 \cdot 8$ & $80 \cdot 7$ & $47 \cdot 0$ & $20 \cdot 6$ & $26 \cdot 4$ & 3,390 & 3,120 & 270 & 3,020 & 89 & 2,930 & 2,630 & None \\
\hline Mean & 37 & $177 \cdot 5$ & $76 \cdot 4$ & $42 \cdot 0$ & $19 \cdot 0$ & $23 \cdot 1$ & 2,990 & 2,650 & 343 & 2,960 & 85 & 2,870 & 2,320 & \\
\hline \multicolumn{15}{|c|}{ Paralysis } \\
\hline 4 & $31^{1,2}$ & $180 \cdot 8$ & $80 \cdot 7$ & $47 \cdot 0$ & $\begin{array}{l}20 \cdot 6 \\
19 \cdot 5\end{array}$ & $\begin{array}{l}26 \cdot 4 \\
27 \cdot 5\end{array}$ & $\begin{array}{l}3,390 \\
3,880\end{array}$ & $\begin{array}{l}3,120 \\
2,950\end{array}$ & $\begin{array}{l}270 \\
930\end{array}$ & 3,020 & $\begin{array}{c}89 \\
59\end{array}$ & $\begin{array}{r}2,930 \\
2,960\end{array}$ & $\begin{array}{l}2,630 \\
2,470\end{array}$ & $\begin{array}{l}\text { None } \\
\text { See text }\end{array}$ \\
\hline \multicolumn{15}{|c|}{ After paralysis } \\
\hline 5 & $\begin{array}{c}17 \\
\text { atment }\end{array}$ & $165 \cdot 5$ & $52 \cdot 4$ & $32 \cdot 1$ & $16 \cdot 3$ & $15 \cdot 8$ & 2,860 & 2,230 & 630 & 2,580 & 85 & 2,500 & 1,930 & None \\
\hline 4 & 31 & $180 \cdot 8$ & $\left\{\begin{array}{l}80 \cdot 7 \\
79 \cdot 6\end{array}\right.$ & $\begin{array}{l}47 \cdot 0 \\
40 \cdot 4\end{array}$ & $\begin{array}{l}20 \cdot 6 \\
19 \cdot 3\end{array}$ & $\begin{array}{l}26 \cdot 4 \\
21 \cdot 1\end{array}$ & $\begin{array}{l}3,390 \\
4,240\end{array}$ & $\begin{array}{l}3,120 \\
2,620\end{array}$ & $\begin{array}{r}270 \\
1,620\end{array}$ & $\begin{array}{l}3,020 \\
3,580\end{array}$ & $\begin{array}{l}89 \\
87\end{array}$ & $\begin{array}{l}2,930 \\
3,490\end{array}$ & $\begin{array}{l}2,630 \\
2,500\end{array}$ & $\begin{array}{l}\text { None } \\
\text { Low } \mathrm{Na} \text { diet }+\mathbf{K}\end{array}$ \\
\hline \multirow[t]{2}{*}{6} & 60 & $183 \cdot 0$ & $84 \cdot 8$ & $38 \cdot 4$ & $20 \cdot 6$ & $17 \cdot 8$ & 3,830 & 2,820 & 1,010 & - & 74 & - & 2,490 & $\begin{array}{l}\text { Digoxin } 0.25 \mathrm{mg} . \\
\text { b.d., Hydrosaluric K } \\
25 \mathrm{mg} \text {. daily }\end{array}$ \\
\hline & & & 89.0 & $41 \cdot 4$ & $24 \cdot 4$ & $17 \cdot 0$ & 4,450 & 3,370 & 1,080 & 2,100 & 110 & 1,990 & 3,260 & $\begin{array}{l}\text { Digoxin } 0.25 \text { mg. } \\
\text { b.d. Low } \mathrm{Na} \text { diet } \\
+\mathrm{K}\end{array}$ \\
\hline
\end{tabular}

${ }^{1}$ Before paralysis

${ }^{2}$ During paralysis

TABLE IV

DERIVED VALUES FOR WATER AND ELECTROLYTE DISTRIBUTION IN FAMILIAL HYPOKALAEMIC PERIODIC PARALYSIS

Extracellular and Intracellular Electrolytes

Residual F Values

\begin{tabular}{|c|c|c|c|c|c|c|c|c|c|c|}
\hline $\begin{array}{l}\text { Patient's } \\
\text { No. }\end{array}$ & $\begin{array}{l}{[N a]_{\text {out }}} \\
(m E q . / l .)\end{array}$ & $\begin{array}{l}{[N a]_{\mathrm{rn}}} \\
(m E q . / l .)\end{array}$ & $\begin{array}{l}\text { Ratio } \\
{[N a]_{\text {out }}} \\
{[N a]_{\text {In }}}\end{array}$ & $\begin{array}{l}{[K]_{\text {out }}} \\
(m E q . / l .)\end{array}$ & $\begin{array}{l}{[K]_{\text {In }}} \\
(m E q . / l .)\end{array}$ & $\begin{array}{l}\text { Ratio } \\
{[K]_{\text {In }}} \\
{[K]_{\text {out }}}\end{array}$ & $\begin{array}{l}{[C l]_{\text {out }}} \\
(m E q . / l .)\end{array}$ & $\begin{array}{l}\text { T.B.W. } \\
(W t) \\
(l .)\end{array}$ & $\begin{array}{l}\text { E.C.W. } N a_{\mathrm{E}}(T . B . W .) \\
(T . B . W .)(m E q .) \\
(l .)\end{array}$ & $\begin{array}{ll}N a_{\mathrm{R}}(T . B . W .) & K_{\mathrm{T}}(T . B . W .) \\
(m E q .) & (m E q .)\end{array}$ \\
\hline
\end{tabular}

\section{Normal}

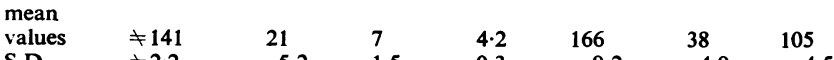

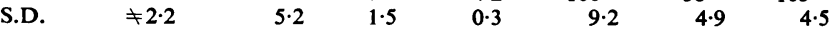

Untreated

135

$\begin{array}{ll}2 & 129 \\ 3 & 142\end{array}$

$\begin{array}{ll}4 & 151 \\ \text { Mean } & 139\end{array}$

$\begin{array}{rr}22 & 6 \cdot 1 \\ 17 & 7 \cdot 6 \\ 13 & 10 \cdot 9 \\ 10 & 15 \cdot 1\end{array}$

$6 \cdot 1 \quad 4 \cdot 3$

$4 \cdot 3 \quad 139$

$\begin{array}{lll}7 \cdot 6 & 4 \cdot 1 & 130 \\ 0.9 & 5 \cdot 1 & 123\end{array}$

Paralysis

$4^{151^{1,2}}$

\begin{tabular}{l}
$16-9 \cdot 9$ \\
\hline
\end{tabular}

$4 \cdot 3$

111

After paralysis

$5 \quad 136$

After treatment

$\begin{array}{ll}4 & 151 \\ 6 & 136 \\ 137\end{array}$

138

$\begin{array}{rrrr}10 & 15 \cdot 1 & 4 \cdot 3 & 111 \\ 34 & 4 \cdot 4 & 3 \cdot 0 & 108\end{array}$

111
108

$3 \cdot 4$

$5 \cdot 2$

158

$15 \cdot 1$

$1 \cdot 8$
$2 \cdot 4$

$4 \cdot 3$

$4 \cdot 5$
$3 \cdot 6$

$3 \cdot 6$
$4 \cdot 5$

111
165

$\overline{117}$

\begin{tabular}{ll}
32 & 109 \\
32 & 109 \\
24 & 108 \\
26 & 115 \\
29 & 110 \\
\hline 26 & 115 \\
36 & 114 \\
30 & 106 \\
26 & 115 \\
37 & 117 \\
\hline 26 & 109 \\
& 120
\end{tabular}

$-3 \cdot 0$
$-3 \cdot 2$
$+1 \cdot 9$
$+1 \cdot 8$
$-0 \cdot 6$
$+1 \cdot 8$
$+1 \cdot 8$
$-2 \cdot 0$
$+1 \cdot 8$
$-4 \cdot 2$
$-4 \cdot 4$
$-3 \cdot 3$

$$
\begin{array}{rlr}
0.0 & + & 20 \\
+0.9 & - & 60 \\
-2.4 & - & 390 \\
-0.8 & - & 60 \\
-0.6 & - & 123
\end{array}
$$$$
\begin{array}{r}
60 \\
-\quad 390 \\
\hline
\end{array}
$$

$+\quad 30$
$-\quad 90$

170
$-\quad 160$

260

-1760
$-\quad 123$

- 490

${ }^{1}$ Before paralysis

'During paralysis

$\begin{array}{rrrr}-0.8 & -60 & -260 & -1,210 \\ -1.9 & +430 & +400 & -1,210 \\ +0.5 & +420 & +290 & -330 \\ & & & \\ -0.8 & -60 & -260 & -1,210 \\ +0.4 & +1,240 & +1,180 & 0 \\ +2.4 & +960 & +590 & - \\ +5.1 & +1,380 & +620 & -1,520\end{array}$


with a mean of $126 \mathrm{mEq} . / 1$. compared with a normal mean of $165 \mathrm{mEq}$./1. and the mean total body potassium is $800 \mathrm{mEq}$. short of the total body potassium predicted on the basis of the total body water.

Mean residual sodium concentration was normal. Total body water was near the expected volume for their age, sex, and weight (derived from nomograms presented by Moore et al., 1963) and its partition between extracellular and intracellular water was normal.

SUBJECT PARALYSED BY FAMILIAL HYPOKALAEMIC PERIODIC PARALYSIS During the attack serum potassium levels fell and so did the intracellular potassium concentration because of the entry of $1 \cdot 1$ litre of extracellular water into the cells. If, as seems likely from the observations of Shy et al. (1961) and Talso et al. (1963), and from the findings in case 5 (vide infra) there is a movement of some chloride (and therefore bromide) into muscle cells during attacks, then the figure of 1.1 litres may be an underestimation, as the extracellular water measured by ${ }^{82} \mathrm{Br}$ would be overestimated. Residual sodium rose considerably and it seems that the administered sodium which produced a rise of exchangeable sodium entered the cells almost at once. Because of the use of sodium bicarbonate to precipitate an attack it is impossible to draw conclusions about sodium movement in spontaneous attacks.

UNTREATED FAMILIAL HYPOKALAEMIC PERIODIC PARALYSIS AFTER AN ATTACK Patient 5 also shows a low total body potassium $(330 \mathrm{mEq}$. less than would be expected on the basis of his total body water). However, the intracellular potassium concentration is nearly normal and the intracellular sodium is high, probably because the volume of intracellular water is reduced. It should again be noted that this apparent reduction in intracellular water may be the result of an expansion of the bromine space (from which the estimate of extracellular water is derived) as a result of the entry of some chloride into his cells during the attack.

EFFECT OF LOW-SALT DIET AND POTASSIUM SUPPLEMENTS ON DISTRIBUTION OF ELECTROLYTES Patient 4 showed a striking change in electrolyte distribution with therapy, accompanied by marked clinical improvement. Muscle strength returned to normal and he was free from attacks. The intracellular potassium concentration rose to a normal level. There was a considerable increase in residual sodium, a paradoxical effect of the low-sodium diet which has also been reported in normal subjects (Cox, Leonard, and Singer, 1962) and in psychiatric patients (Coppen and Shaw, 1965). These increases in cation concentrations were brought about both by an increase in body sodium and potassium and by a fall in intracellular water. The patient gained 7.4 litres of total body water. but only $1.1 \mathrm{~kg}$. of body weight between the two tests. This apparent discrepancy may be explained by opposite changes in the amount of body fat and total body water. The patient had been on a low-salt diet and potassium supplements for eight months between the tests and had lead an increasingly active life and it is probable that his body fat decreased and his lean body mass (and total body water) increased during this time.

Patient 6 is considered separately because of myopathy and his cardiac condition and treatment. On both occasions there were significant electrolyte abnormalities which cannot be accounted for by cardiac failure (Moore et al., 1963). The intracellular residual sodium concentration was considerably above normal when he was taking a diuretic and when on a low-sodium diet with potassium supplements. His intracellular potassium concentration $(117 \mathrm{mEq} . / \mathrm{l}$.) was very low. The rise of extracellular water from 20.6 to 24.4 when he was on the low-sodium diet was the result of slight cardia failure.

DISCUSSION

We found that untreated patients, between attacks of paralysis, have considerably reduced body potas sium and intracellular potassium concentration. Total body water and water distribution are normal. Exchangeable sodium and residual sodium are normal. Treatment with a low-sodium diet and potassium in patient 4 produced a striking change in electrolyte distribution and clinical improvement. Intracellular potassium concentration returned to normal and residual sodium concentration was elevated well above normal.

Conn and Streeten (1960) reported high exchangeable and intracellular sodium values in patients with familial hypokalaemic periodic paralysis which, they suggested, supported their hypothesis that inter- $:$ mittent aldosteronism is a cause of this condition. However, we were unable to confirm these findings in $\delta$ our untreated patients. After treatment with a lowsalt diet and potassium supplements, which is 0 known to be a powerful stimulus to aldosterone secretion, we did find an increased exchangeable and residual sodium value and it seems to us that far from being implicated as a cause of attacks, a raised $\sigma$ aldosterone secretion is likely to be of benefit to $N$ the patient because this regime has a therapeutic N effect. It is therefore perhaps not surprising that 
Shy et al. (1961) observed no deleterious effect after the intravenous administration of aldosterone to one patient. Shy et al. (1961) and McArdle (1963) have pointed out further difficulties in accepting Conn and Streeten's theory of intermittent aldosteronism as a cause of familial hypokalaemic periodic paralysis. In particular, the fall in serum potassium in aldosteronism is associated with a high excretion of potassium in the urine in contrast to the movement of potassium into cells in familial hypokalaemic periodic paralysis.

The fall in the level of serum potassium during attacks of paralysis has naturally led to the suggestion that paralysis is due to hyperpolarization of the muscle membrane. However, during the period of paralysis we found a slight fall in intracellular potassium concentration as a result of an increase in intracellular water. Although the ratio of intracellular to extracellular potassium concentration, which is the main factor in determining the resting membrane potential, rose by $38 \%$ from the untreated preparalytic state (ratio $26: 1$ ) to the paralytic state (ratio 36:1), a significant finding was that this ratio was almost the same when the patient was paralysed (ratio 36:1) as when muscle power was fully restored following treatment (ratio 37:1). Furthermore, since the normal ratio is $38: 1$, our findings are in agreement with the observations of Shy et al. (1961) and Creutzfeldt, Abbott, Fowler, and Pearson (1963) who found, using microelectrodes, that the muscle membrane potential was normal during an attack of paralysis. It seems unlikely therefore that the abnormality in muscle function is due to hyperpolarization of the muscle membrane.

Recent work, reviewed by Adrian (1964), has focused attention on the peculiar properties of the sarcoplasmic reticulum with regard to its permeability to potassium. Hodgkin and Horowicz (1959) have shown that at varying external potassium concentrations the potassium permeability in muscle is small for outward potassium movement, but large for inward potassium movement. This 'anomalous rectification' has puzzled physiologists because these differing permeabilities for movement of potassium in opposite directions appears to be the reverse of that necessary to explain the recovery and loss of potassium during an impulse. Adrian presents evidence to suggest that the walls of the T-system component of the sarcoplasmic reticulum are the site of this anomalous permeability to potassium. He further suggests that this property is intimately concerned in the process of excitation-contraction coupling and that following excitation the failure of outward potassium movement across the T-system walls allows the inward movement of a negatively charged calcium ion complex which initiates con- traction. If these hypotheses are confirmed it can be seen that any disturbance in the permeability to potassium across the T-system is liable seriously to interfere with muscle contraction. Abnormalities of permeability to potassium in the membrane at that site may therefore be responsible for the paralysis of both familial hypokalaemic periodic paralysis and familial hyperkalaemic periodic paralysis. It is significant that the most conspicuous structural abnormality on electron microscopic examination of muscle biopsy specimens in both conditions (Shy et al., 1961; Pearson, 1964) is fluid-filled spaces thought to be dilatations of the sarcoplasmic reticulum.

\section{SUMMARY}

Distribution of water, sodium, and potassium has been studied by a multiple isotope technique in six patients with familial hypokalaemic periodic paralysis, one of whom had also developed a proximal myopathy.

Between attacks all patients had a low total body potassium and low intracellular potassium concentration. Residual sodium concentration was normal. Total body water and its partition between intracellular and extracellular spaces was normal.

Treatment with a low-sodium diet and potassium supplements in one patient resulted in return of intracellular potassium concentration to normal, a considerable elevation of residual sodium concentration, and a decrease in the volume of intracellular water. There was a marked clinical improvement.

During an induced attack in one patient intracellular potassium concentration fell slightly, due to the entry of relatively greater amounts of water than potassium into the cells. The ratio of intracellular to extracellular potassium concentration was normal when he was paralysed and also when muscle power was fully restored on treatment with a low-sodium diet and potassium supplements. Paralysis is therefore not due to hyperpolarization of the muscle cell membrane. The aetiology of this condition is discussed and it is suggested that the primary disturbance may be in the transport of potassium across the sarcoplasmic reticulum.

We are very grateful to Professor R. W. Gilliatt and to Drs. S. P. Meadows, R. Ross Russell, and Denis Williams for permission to study their cases, and to Drs. Brian McArdle, R. Ross Russell, and D. M. Shaw for their helpful advice in the preparation of the paper. We are indebted to Mr. J. Vennart, of the Medical Research Council's Radiological Protection Service, for estimating total body potassium in our patients. We also wish to thank Mr. S. G. White for his technical assistance, Miss L. Ridge for the secretarial workers and Mr. J. E. Bailey 
and the nursing staff of Greenbank Ward at West Park Hospital for their invaluable help in carrying out these investigations.

\section{REFERENCES}

Adrian, R. H. (1964). In The Cellular Functions of Membrane Transport, pp. 55-70. Edited by J. F. Hoffman. Prentice-Hall, Englewood Cliffs, New Jersey.

Anderson, E. C. (1963). Three-component body composition analysis based on potassium and water determinations. Ann. N.Y. Acad. Sci., 110, 189-210.

Bekény, G. (1961). Über irreversible Muskelveränderungen bei der paroxysmalen Lähmung auf Grund bioptischer Muskeluntersuchungen. Dtsch. Z. Nervenheilk., 182, 119-154.

Conn, J. W., and Streeten, D. H. P. (1960). Periodic paralysis. In The Metabolic Basis of Inherited Disease. Edited by J. B. Stanbury, J. B. Wyngaarden, and D. S. Frederickson, pp. 867-918, McGraw-Hill, New York.

Coppen, A., and Shaw, D. M. (1963). Mineral metabolism in melancholia. Brit. med. J., 2, 1439-1444.

,-- (1965). Unpublished observations.

Cox, J. R., Leonard, P. J., and Singer, B. (1962). Changes in sodium distribution in body fluid compartments and urinary aldosterone excretion. Clin. Sci., 23, 13-26.

Creutzfeldt, O. D., Abbott, B. C., Fowler, W. M., and Pearson, C. M. (1963). Muscle membrane potentials in episodic adynamia. Electroenceph. clin. Neurophysiol., 15, 508-519.
Grob, D., Johns, R. J., and Liljestrand, Ä. (1957). Potassium movement in patients with familial periodic paralysis. Relationship to the defect in muscle function. Amer. J. Med., 23, 356-375.

Hodgkin, A. L., and Horowicz, P. (1959). The influence of potassium and chloride ions on the membrane potential of single muscle fibres. J. Physiol. (Lond.), 148, 127-160.

Jantz, H. (1947). Stoffwechseluntersuchungen bei paroxysmaler Lähmung. Nervenarzt, 18, 360-378.

Lindegård, B. (1953). Variations in human body-build. Acta Psychiat. (Kbh.), suppl. 86.

McArdle, B. (1963). Metabolic myopathies. Amer. J. Med., 35, 661-672.

- , and Merton, P. A. (1952). The behaviour of radio-potassium in man. J. Physiol. (Lond.), 116. 51 P-52P.

Moore, F. D., Olesen, K. H., McMurrey, J. D., Parker, H. V., Ball, M. R., and Boyden, C. M. (1963). The Body Cell Mass and its Supporting Environment. Saunders, Philadelphia.

Oppenheim, H. (1891). Neue Mittheilungen über den von Professor Westphal beschriebenen Fall von periodischer Lähmung aller vier Extremitäten. Charité-Ann., 16, 350-372.

Pearson, C. M. (1964). The periodic paralyses: Differential features and pathological observations in permanent myopathic weakness. Brain, 87, 341-354.

Shy, G. M., Wanko, T., Rowley, P. T., and Engel, A. G. (1961). Studies in familial periodic paralysis. Exp. Neurol., 3, 53-121.

Talso, P. J., Glynn, M. F., Oester, Y. T., and Fudema, J. (1963). Body composition in hypokalemic familial periodic paralysis. Ann. N.Y. Acad. Sci., 110, 993-1008.

Vastola, E. F., and Bertrand, C. A. (1956). Intracellular water and potassium in periodic paralysis. Neurology (Minneap.), 6, 523-528. 